\title{
PERAN ENTREPRENEURSHIP BAGI PENGEMBANGAN KAMPUNG WISATA ORGANIK PESONA AGRO
}

\author{
Ahmad Nizar Yogatama \\ Sekolah Tinggi Manajemen Informatika dan Komputer ASIA Malang
}

\section{ABSTRAKSI}

Entrepreneurship seharusnya berperan penting bagi pengembangan usaha Kampung Wisata Organik Pesona Agro. Hal tersebut karena potensi yang dimiliki saat ini seperti green house, air organik dan kolam ikan seharusnya dapat dikembangkan dan berpotensi untuk meningkatkan hasil produksi. Tujuan dari penelitian ini adalah untuk mengetahui bagaimana peran entrepreneurship dan kualitas sumber daya manusia terhadap pengembangan usaha Kampung Wisata Organik Pesona Agro. Hasil penelitian menunjukkan bahwa entrepreneurship belum berkontribusi terhadap pengembangan usaha yang dilakukan karena pengembangan usaha yang dilakukan yaitu penanaman tanaman organik diatas kolam ikan sehingga terjadi simbiosis mutualisme antara tanaman organik dan ikan masih terbatas konsep. Kemudian, kualitas sumber daya manusia berkontribusi terhadap keahlian dan keterampilan mengembangkan usaha tanaman organik, dimana saat ini Kampung Wisata Organik Pesona Agro memiliki keterbatasan ahli serta waktu dalam pengelolaan tanaman organik karena dikerjakan sebagai pekerjaan sampingan.

Kata Kunci: Entrepreneurship, Pengembangan Usaha, Wisata Organik

\begin{abstract}
Entrepreneurship necessarily present an important role for business development of Kampung Wisata Organik Pesona Agro. It is coused by the potential such as green house, organic water and fish ponds should be developed and the potential to improve production. The purpose of this study was to determine how the role of entrepreneurship and human resources could developed Kampung Wisata Organik Pesona Agro. The results showed that entrepreneurship has not contributed yet. Then, the quality of human resources of Kampung Wisata Organik Pesona Agro has its limitations as well as time management expert organic crops because it does as a side job.

Keyword: Entrepreneurship, Business Development, Organic Tourism
\end{abstract}

\section{PENDAHULUAN}

Dari seluruh wilayah di Indonesia, Kota Malang merupakan salah satu daerah tujuan wisatawan lokal. Melihat potensi yang dimiliki sebagai daerah tujuan wisata, Pemerintah Kota Malang kemudian mulai mengembangkan wilayah - wilayah yang dapat ditingkatkan sarana dan prasarananya sehingga dapat meningkatkan jumlah wisatawan. Konsep yang dikembangkan oleh Pemerintah Kota Malang adalah wisata rakyat yang sifatnya gratis dan mudah dijangkau oleh semua masyarakat yang mana wilayah yang dijadikan percontohan adalah Kampung Warna - Warni di daerah Jodipan.

Pada tahun 2016, Pemerintah Kota Malang mengadakan Festival Rancang Malang yaitu Lomba merencanakan Kampung Tematik. Tujuannya adalah pemberdayaan potensi kampung yang terdapat di setiap Kelurahan dan
Kecamatan Kota Malang sehingga kesejahteraan ekonomi masyarakat meningkat. Tujuan selanjutnya adalah mengurangi daerah kumuh dan penciptaan wisata rakyat yang ramah lingkungan dan mudah dijangkau semua kalangan masyarakat, khususnya masyarakat Kota Malang.

Kampung Tematik yang dijadikan sebagai percontohan oleh Pemerintah Kota Malang adalah Kampung Warna - Warni. Kampung tersebut berhasil menjadi wilayah wisata inovatif yang ramah lingkungan dan berhasil meningkatkan jumlah wisatawan. Konsep tersebut kemudian ingin dikembangkan dan diterapkan terhadap kampung - kampung lain yang sudah memiliki potensi yang dapat dikembangkan. Salah satu kampung yang berpotensi untuk dikembangkan adalah Kampung Wisata Organik Pesona Agro yang terletak Kelurahan Wonokoyo Kecamatan 
Kedung- kandang. Potensi yang dapat dikembangkan adalah tanaman organik.

Kampung Wisata Organik Pesona Agro, memiliki beberapa aset seperti green house, Air Organik dan Kolam Ikan. Kampung Wisata Organik Pesona Agro berawal dari pembentukan Kelompok Tani yang terdiri dari purnawirawan yang tertarik dan memiliki kemauan untuk fokus pada pengembangan lingkungan, dimana hal tersebut kemudian diikuti oleh masyarakat sekitar yang ada di Perumahan Buring Raya. Kelompok Tani tersebut terletak di RW. 04 yang diberi nama "Pesona Agro". Nama Pesona Agro kemudian dijadikan sebagai nama Kampung, sehingga saat ini disebut sebagai Kampung Wisata Organik Pesona Agro. Kampung Wisata tersebut, telah berpartisipasi dan memenangkan lomba Kampung Bersinar sebagai juara III yang diselenggarakan juga oleh Pemerintah Kota Malang pada tahun 2013 dan membawa nama Kampung Organik sebagai salah satu ikon Kelurahan Wonokoyo Kecamatan Kedungkandang.

Walaupun Kampung Wisata Organik Pesona Agro memiliki beberapa aset seperti green house, kolam ikan dan air organik, namun keterbatasan entrepreneurship menyebabkan hasil produksi dan pengembangan usaha yang kurang maksimal. Penyebabnya adalah pengelolaan tanaman organik hanya berada di RW. 04 yaitu wilayah Kelompok Tani Pesona Agro, kemudian air organik dikelola oleh HIPAM, dan untuk kolam ikan berada di bawah pengelolaan Karang Taruna dimana saat ini belum dimanfaatkan dengan baik. Saat ini Kelompok Tani Pesona Agro, HIPAM serta Karang Taruna berkerjasama, namun entrepreneurship yang belum merata menyebabkan produksi tanaman organik tidak stabil, hal tersebut juga ditambah dengan pengaruh cuaca.

Keterbatasan entrepreneurship tentu berkontribusi terhadap Kualitas Sumber Daya Manusia (SDM) pengelola yang ada di Kampung Wisata Organik Pesona Agro. Apabila ditinjau dari sudut pandang organisasi bisnis, maka kualitas SDM terbaik wajib dimiliki untuk mencapai hasil yang maksimal. Kualitas SDM yang terdapat di Kampung Wisata Organik Pesona Agro saat ini yaitu mereka memiliki keterbatasan ahli dan ketersediaan waktu dalam pengelolaan tanaman organik karena mayoritas pengelola adalah purnawirawan dan merupakan pekerjaan sampingan.

Apabila ditinjau dari ketersediaan generasi muda, Kampung Wisata Organik Pesona Agro melalui Karang Taruna memiliki kualitas Sumber Daya Manusia yang baik. Karena anggota Karang Taruna adalah kaum terpelajar seperti mahasiswa dan siswa. Kondisi tersebut menyebabkan Karang Taruna memiliki posisi strategis. Apabila dicermati, tujuan pembentukan Karang Taruna adalah sebagai wadah bagi generasi - generasi muda agar memiliki tempat yang positif dalam menyalurkan bakat dan kreativitas yang dimiliki, selain untuk mengembangkan kemampuan dan keterampilan individu (Wispandono et al., 2014). Saat ini, Karang Taruna memberdayakan generasi mudanya untuk mengelola green house diluar jam belajar atau kuliah, seperti hari sabtu dan minggu, atau sore hari.

Pertanian secara organik seharusnya mampu menciptakan suatu sistem pertanian yang mengoptimalkan kesehatan dan produktivitas agro-ekosistem secara alami sehingga mampu menghasilkan pangan dan serat yang cukup, berkualitas dan berkelanjutan. Berdasarkan hal tersebut, tanaman organik yang diantaranya yaitu sayuran organik memiliki banyak manfaat. Manfaat dari tanaman organik diantaranya memiliki kandungan gizi tinggi, lebih segar dan tahan lama, serta baik untuk perkembangan anak. Realita yang terjadi saat ini adalah seperti yang ada di Kampung Wisata Organik Pesona Agro, tidak banyak petani tanaman organik yang memahami manfaat olahan secara organik bagi tubuh. Ketidaktahuan tersebut kemudian berdampak terhadap hasil olahan tanaman organik.

Kampung Wisata Organik Pesona Agro selama ini telah berhasil melaksanakan produksi sayuran organik. Sejak menjadi juara III dalam lomba kampung bersinar yang dihelat pada tahun 2013, Kampung Wisata Organik Pesona Agro telah berkerjasama dengan PT. Indomarco (Indomaret) untuk menjual tanaman organik. Kerjasama tersebut berhasil meningkatkan penjualan sehingga produksi sayuran organik meningkat. Namun, kerjasama tersebut pada tahun 2015 harus berhenti karena kesalahpahaman sehingga berdampak terhadap penjualan dan hasil produksi tanaman organik mengalami penurunan.

Konsistensi dan peningkatan produksi tanaman organik tidak akan pernah tercapai 
apabila Kampung Wisata Organik Pesona Agro belum melakukan perbaikan dan pengembangan usaha. Perbaikan yang perlu dilakukan adalah mengembangkan dan meningkatkan kualitas SDM melalui pelatihan, seminar ataupun belajar secara otodidak. Terkait dengan pengembangan usaha, Kampung Wisata Organik Pesona Agro dapat menggunakan aset yang telah dimiliki dan melakukan inovasi produk dari hal tersebut melalui generasi - generasi muda Karang Taruna. Hal tersebut sesuai dengan tujuan dari Karang Taruna yaitu membantu memberdayakan masyarakat agar tidak menjadi penyandang masalah kesejahteraan sosial (PMKS), khususnya generasi muda yang ada di wilayah sekitar agar potensial dan mandiri (Handayani et al., 2015).

Salah satu fakta menarik tentang tanaman organik adalah belum banyak konsumen yang memahami manfaat melakukan konsumsi terhadap tanaman organik, seperti yang dialami oleh Kampung Wisata Organik Pesona Agro. Hal tersebut menyebabkan proses produksi tanaman organik terganggu. Rendahnya pengetahuan akan manfaat melakukan konsumsi tanaman organik juga disebabkan oleh harga jual bahan kimia yang lebih murah dan proses panjang yang dibutuhkan agar hasil produksi tanaman organik diakui sebagai organik.

Rendahnya pengetahuan tentang manfaat dari konsumsi tanaman organik juga berasal dari harga jual lebih rendah dibandingkan manfaat secara jangka panjang. Tanaman nonorganik adalah makanan yang mengandung bahan kimia berbahaya, dan berpotensi menyebabkan penyakit seperti penyempitan pembuluh darah, kolesterol, autis, tumor hingga kanker. Dibutuhkan sosialisasi, upaya serta konsistensi Kampung Wisata Organik Pesona Agro agar konsumen mau melakukan konsumsi terhadap tanaman organik walaupun harga jual tinggi, daripada konsumsi tanaman non-organik dengan harga lebih murah.

Berdasarkan pemaparan tersebut, tujuan penelitian ini adalah melihat bagaimana peran entrepreneurship serta kualitas Sumber Daya Manusia bagi pengembangan usaha di Kampung Wisata Organik Pesona Agro yang ada di Kelurahan Wonokoyo Kecamatan Kedungkandang Kota Malang. Penelitian ini diharapkan mampu memberikan solusi terhadap Kampung Wisata Organik Pesona Agro sehingga dapat meningkatkan kualitas Sumber Daya Manusia yang dimiliki saat ini melalui penanaman entrepreneurship sehingga berdampak pada pengembangan usaha secara jangka panjang. Selain itu, dengan pengelolaan dan proses produksi yang lebih baik mampu menciptakan kesejahteraan ekonomi di Kampung Wisata Organik Pesona Agro.

\section{Entrepreneurship}

Entrepreneurship (kewirausahaan) merupakan kombinasi dari perilaku inovatif, proaktif serta berani menanggung risiko sehingga mampu menciptakan suatu nilai dalam organisasi (McDougall dan Oviatt, 2010). Oswari (2005) menambahkan bahwa mereka yang melakukan wirausaha adalah mereka yang memiliki keberanian untuk melakukan usaha secara mandiri dan berani menanggung segala risiko yang akan dihadapi serta berdedikasi untuk menjalankan bisnis hingga berhasil.

Saat ini, Kampung Wisata Organik Pesona Agro telah bertindak proaktif melalui kerjasama dengan PT. Indomarco. Namun, Kampung Wisata Organik Pesona Agro belum banyak melakukan inovasi terhadap produksi tanaman organik karena keterbatasan ahli dan waktu. Berdasarkan fakta yang ada, komitmen untuk berbisnis tanaman organik hingga berhasil hanya dimiliki oleh pemimpin Karang Taruna, HIPAM dan Kelompok Tani sebagai pengelola Kampung Wisata Organik Pesona Agro.

Agar mampu menciptakan suatu pengaruh maka para pelaku yang memiliki kewirausahaan harus mengembangkan karakteristik individu yang fleksibel (CrecenteRomero et al., 2016). Dalam hal ini, seharusnya pemimpin Karang Taruna, HIPAM dan Kelompok Tani harus memiliki karakteristik individu yang fleksibel. Era modern saat ini, pertanian organik seharusnya menjadi "Primadona" karena kandungan gizi tanaman organik sangat banyak serta baik untuk perkembangan anak. Bahkan, pertanian organik mampu mengubah produktivitas pertanian menjadi semakin tinggi dan berdaya saing secara lokal, nasional maupun internasional.

Apabila kewirausahaan mampu dimaksimalkan oleh Karang Taruna, Kelompok Tani maupun HIPAM, maka Kampung Wisata Organik Pesona Agro dapat berkembang. Manfaat dari pengembangan usaha yang berhasil dilakukan diantaranya adalah mampu mengurangi pengangguran, terutama lulusan Perguruan Tinggi yang ada di wilayah Kampung Wisata Organik Pesona Agro, 
sehingga dapat membantu dalam pengembangan usaha wisata organik agar tercipta lapangan pekerjaan (Siswoyo, 2009).

Salah satu bentuk kewirausahaan adalah social entrepreneurship yaitu sebuah perilaku yang dilaksanakan dalam bentuk pelaksanaan nilai sosial melalui berbagai kesempatan oleh individu, kelompok atau organisasi terhadap lingkungan yang ada agar menjadi lebih baik (Weerawardena dan Mort, 2006; Nicholls, 2009). Hal tersebut sesuai dengan apa yang dilakukan oleh Kampung Wisata Organik Pesona Agro yaitu mengelola tanaman organik agar lingkungan menjadi lebih asri.

\section{Kualitas Sumber Daya Manusia}

Kualitas adalah suatu keseluruhan ciri dan karakteristik yang dimiliki suatu produk dan jasa yang dapat memberikan kepuasan pada penggunanya (Yulianto, 2010). Hal ini bermakna bahwa Kampung Wisata Organik Pesona Agro dianggap berkualitas apabila mampu memenuhi kepuasan pelanggan. Hardiningsih (2011) menambahkan bahwa kualitas adalah suatu kondisi dinamis yang berhubungan dengan produk, jasa manusia, proses, dan lingkungan yang memenuhi atau melebihi harapan pihak yang menginginkannya. Kualitas adalah conformance dan bukan kemewahan. Suatu produk dikatakan sebagai produk yang berkualitas apabila produk tersebut mampu menimbulkan kepuasan konsumennya, sehingga pemilik usaha harus berusaha untuk mengetahui apa yang diinginkan oleh konsumennya (Ciptani, 2004). Tanaman Organik adalah salah satu bentuk usaha di bidang pertanian yang saat ini sedang giat untuk dikembangkan. Salah satu bentuk usaha tani seperti Kampung Wisata Organik Pesona Agro sebenarnya memiliki definisi yaitu suatu tempat atau bagian dari permukaan bumi dimana kegiatan pertanian diselenggarakan oleh seorang petani tertentu apakah ia seorang pemilik atau orang yang digaji.

\section{Tanaman Organik}

Harsojo \& Mellawati (2009) mengatakan bahwa tanaman organik adalah tanaman yang sistem budidayanya tidak menggunakan pupuk sintetis melainkan pupuk bahan alam atau organik, sedangkan tanaman non-organik merupakan tanaman yang sistem budidayanya menggunakan pupuk sintetis. Kampung Wisata Organik Pesona Agro dalam pengelolaannya menggunakan bahan - bahan organik, yaitu air yang berasal dari sumber dan dikelola oleh HIPAM. Kemudian, Kelompok Tani Pesona Agro serta Karang Taruna menggunakan green house sebagai tempat penanaman tanaman organik bekerjasama dengan HIPAM dan menggunakan pupuk alami. Tanaman organik adalah tanaman yang diproduksi tanpa menggunakan bahan - bahan kimia sintetis. Kelebihan tanaman organik diantaranya mengandung lebih banyak antioksidan dan zat nutrisi seperti vitamin C, zat besi, magnesium, fosfor, dan mineral serta phytonutrinets yaitu zat gizi dalam buah dan tanaman yang dapat melawan kanker. Selain itu lingkungan pertanian tanaman organik juga lebih aman dan ranah, khususnya terhadap ekosistem lingkungan hidup, seperti tanah, udara dan air (Widodo et al., 2016). Sinaga et al., (2014) menambahkan bahwa tanaman organik adalah tanaman yang cukup aman bila dikonsumsi, mengingat dalam budidayanya lebih mengandalkan bahan - bahan alami, seperti menggunakan pupuk organik dan tidak menggunakan pestisida kimia.

\section{METODOLOGI PENELITIAN Tipe Penelitian}

Penelitian ini dilakukan di Kampung Wisata Organik Pesona Agro, lebih tepatnya berada di Perumahan Buring Raya Kelurahan Wonokoyo Kecamatan Kedungkandang. Penelitian ini dilaksanakan selama bulan November 2016. Kampung Wisata Organik Pesona Agro dipilih karena pernah menjadi juara III dan mendapatkan penghargaan pada tahun 2013. Kemudian, Kampung Wisata Organik Pesona Agro memiliki potensi yang bisa dikembangkan seperti green house, air organik dan kolam ikan. Selanjutnya adalah Kampung Wisata Organik pesona Agro pernah berkerjasama dengan PT. Indomarco melalui Indomaret sebagai media distribusi hasil tanaman organik. Selama bulan November 2016, peneliti melakukan pengumpulan, pengamatan serta wawancara terhadap pihak pihak terkait untuk menjawab pertanyaan penelitian.

\section{Jenis Penelitian}

Peneliti menggunakan tipe penelitian deskriptif kualitatif, yaitu penelitian yang mendeskripsikan secara sistematis, faktual dan akurat mengenai data - data atau fakta - fakta yang berhasil diperoleh. Peneliti dalam 
penelitian ini melakukan pengamatan secara partisipatoris.

\section{Populasi dan Sampel}

Populasi yang digunakan dalam penelitian ini adalah Warga Perumahan Buring Raya Kelurahan Wonokoyo Kecamatan Kedungkandang. Sampel yang digunakan dalam penelitian ini adalah warga Perumahan Buring Raya yang tergabung dalam Kelompok Tani Pesona Agro, Karang Taruna serta HIPAM. Penelitian ini menggunakan metode penelitian deskriptif kualitatif, sehingga peneliti akan melakukan pengamatan secara langsung atau partisipatoris dan terdapat informan yang akan diwawancarai untuk mendapatkan jawaban atas pertanyaan penelitian. Informan yang digunakan, ditentukan berdasarkan kebutuhan data yang dibutuhkan oleh penelitian ini. Dalam penelitian ini, data yang dibutuhkan adalah warga Perumahan Buring Raya yang tergabung dalam Kelompok Tani Pesona Agro, Karang Taruna serta HIPAM.

\section{Jenis Data}

Jenis data yang digunakan dalam penelitian ini yaitu data primer dan data sekunder. Data primer adalah data yang diperoleh melalui wawancara informan, sedangkan data sekunder adalah data yang didapatkan dari sumber - sumber pendukung seperti media massa dan dokumen dari Pemerintah Kota di Kelurahan Wonokoyo serta Kecamatan Kedungkandang. Data - data yang telah dikumpulkan tersebut, kemudian di analisis untuk menjawab pertanyaan penelitian.

\section{Teknik Analisa Data}

Penelitian ini bersifat deskriptif, sehingga peneliti akan berusaha untuk memberikan keterangan berupa gambaran, kemudian memaparkan serta mengintepretasikan objek yang diteliti dengan kata - kata secara sistematis serta faktual. Dalam penelitian ini, peneliti melakukan analisa data menggunakan analis is deskriptif berdasarkan metode analisis interaksi menurut Miles dan Huberman. Adapun aktivitas yang digunakan dalam analisis data yaitu: pengumpulan data (data collection), pereduksian data (data reduction), penyajian data (data display) dan penarikan kesimpulan (verification).

\section{HASIL PENELITIAN}

Kampung Wisata Organik Pesona Agro merupakan wisata yang terletak di daerah Perumahan Buring Raya. Perumahan tersebut dihuni oleh berbagai macam penduduk dengan latar belakang pekerjaan, pendidikan serta umur yang berbeda - beda. Namun, mayoritas warga Perumahan Buring Raya adalah purnawirawan dan diantaranya masih aktif.

Kampung Wisata Organik Pesona Agro apabila dicermati sebenarnya belum sepenuhnya menjadi kampung, karena berada di Perumahan. Selain itu, Wisata Organik Pesona Agro yang sebenarnya hanya terletak di salah satu lokasi yang ada di Perumahan Buring Raya, yaitu RT. 01. Alasan RT. 01 menjadi tempat Wisata Organik Pesona Agro yang sebenarnya adalah RT. 01 merupakan kediaman dari Kelompok Tani Pesona Agro.

Kampung Wisata Organik Pesona Agro hingga saat ini telah mendapatkan perhatian yang serius dari Pemerintah. Perhatian tersebut diantaranya adalah pemberian green house dari Badan Ketahanan Pangan. Selain itu, terkait dengan kolam ikan Kampung Wisata Organik Pesona Agro mendapatkan bibit ikan dan pompa pada kolam dari Dinas Pertanian Bidang Perikanan. Namun, hibah tersebut belum mampu dikelola secara efektif dan efisien. Penyebabnya adalah pengelolaan tanaman organik dilakukan sebagai pekerjaan sampingan. Hal ini kemudian berdampak pada hasil produksi tanaman organik.

Kelompok Tani Pesona Agro merupakan pelopor pengelolaan tanaman organik di Perumahan Buring Raya. Setelah Kelompok Tani tersebut berbadan hukum, Pemerintah Kota Malang pada tahun 2013 menyelenggarakan event Kampung Bersinar dan Kampung Wisata Organik Pesona Agro menjadi juara III dan mendapatkan penghargaan berupa sertifikat dan uang yang berasal dari dana CSR (Corporate Social Responsibility) Perushaaan Listrik Negara (PLN). Kemenangan tersebut menjadi awal dedikasi warga Perumahan Buring Raya menanam tanaman organik. Namun, ketika Kampung Bersinar mampu menjadi momen terbentuknya Kampung Wisata Organik, pada tahun 2015 animo warga untuk mau berdedikasi kembali terhadap tanaman organik sudah jauh berbeda. Penyebabnya adalah keterbatasan waktu.

Karang Taruna di Kampung Wisata Organik Pesona Agro memiliki generasi muda 
yang memiliki inovasi dan kreativitas mumpuni karena mereka adalah pelajar dan mahasiswa, hanya saja waktu menjadi kendala utama bagi mereka untuk ikut berkontribusi secara penuh bagi pengelolaan tanaman organik. Kendala tersebut saat ini dapat diselesaikan dengan cara memberikan kegiatan rutin setiap akhir pekan, yaitu hari sabtu dan minggu untuk mengelola tanaman organik. Selain itu, Karang Taruna juga membantu dalam pengelolaan green house. Namun, apabila dicermati tidak semua green house berada di bawah wewenang Karang Taruna, beberapa diantaranya ada di bawah wewenang Kelompok Tani Pesona Agro, sedangkan HIPAM bertindak sebagai penyalur air organik ke seluruh penjuru Perumahan Buring Raya, tidak terkecuali green house.

Secara umum, lomba Kampung Bersinar merupakan momen istimewa bagi setiap warga Perumahan Buring Raya, dimana hal tersebut kemudian berdampak pada animo luar biasa untuk menanam tanaman organik di setiap pekarangan rumah. Namun, ketika kerjasama mulai diperlukan untuk mengembangkan usaha, Kampung Wisata Organik Pesona Agro belum memiliki motivasi utama terlebih entrepreneurship sebagai dasar untuk bertindak dan bersikap seperti menghadapi event Kampung Bersinar yang pernah diadakan sebelumnya. Untuk meningkatkan kesadaran petani tanaman organik, mereka membutuhkan motivasi dan ilmu pemasaran secara berkelanjutan, yaitu pembinaan untuk memotivasi dan cara memasarkan produk olahan tanaman organik yang lebih baik sehingga Kampung Wisata Organik Pesona Agro dapat menjadi percontohan bagi pengelolaan tanaman organik secara nasional.

Apabila tanaman organik dikelola dengan baik, maka harga jual produk tanaman organik menjadi lebih tinggi karena aman dari bahan kimia dan bergizi ketika dikonsumsi. Biaya operasional mengelola tanaman organik terbukti lebih rendah karena untuk pupuk dan pestisida cukup menggunakan kotoran ternak dan sisa hasil panen atau rumput liar sebagai sumber hara. Lingkungan pertanian organik memiliki lingkungan yang sehat karena petani tidak terkena polusi yang diakibatkan oleh pupuk non-organik dalam produksi pertanian. Kemudian, pengelolaan secara organik mampu memperbaiki dan menjaga $\mathrm{Ph}$ tanah, mengurangi limbah pertanian, kualitas air tetap terjaga, meningkatkan populasi mikroorganisme tanah, sehingga tanah selalu terlindungi dengan mulsa organik serta meminimalkan gangguan aktivitas biota tanah karena pengelolaan tanah yang baik secara organik.

Kegiatan pembinaan dalam bentuk pemberian motivasi serta ilmu pemasaran ini adalah untuk meningkatkan kesadaran masyarakat RW. 04 Kelurahan Wonokoyo bahwa tanaman organik memiliki pesona luar biasa jika di rawat dengan prosedur hingga kualitas yang baik dan secara berkelanjutan. Petani tanaman organik secara umum sangat antusias terkait pengelolaan tanaman organik berkualitas yang dapat digunakan untuk pengembangan usaha. Oleh karena itu, upaya pembinaan perlu dilakukan di Kelurahan Wonokoyo, terlebih adanya program dari Pemerintah Kota Malang yaitu Lomba Kampung Tematik, selain Kelurahan Wonokoyo juga mendapatkan bantuan dalam bentuk Green House serta memiliki bank sampah, dimana jika dikombinasikan dengan baik mampu menjadi ikon pendorong pertumbuhan kesejahteraan masyarakat Kota Malang, khususnya bagi warga Kelurahan Wonokoyo RW.04 Kecamatan Kedungkandang Kota Malang.

Melalui momentum Festival Rancang Malang pada tahun 2016, Kampung Wisata Organik Pesona Agro melalui Kelompok Tani Pesona Agro, Karang Taruna serta HIPAM telah merencanakan untuk mengembangkan pengelolaan kolam ikan untuk penanaman tanaman organik. Pengembangan tersebut untuk menanggulangi keterbatasan tempat yang dimiliki oleh Kampung Wisata Organik Pesona Agro. Saat ini salah satu green house yang dikelola Karang Taruna mampu menghasilkan sekitar 2 ton sayuran, apabila tidak terkendala masalah cuaca. Pengembangan kolam ikan tersebut nanti akan menciptakan simbiosis mutualisme antara tanaman organik dan ikan, dimana ikan yang dimaksud adalah ikan air tawar, dan simbiosis mutualisme yang dimaksud adalah air kolam selain untuk ikan, dapat digunakan untuk mengairi tanaman organik. Terkait pengembangan usaha tersebut, sayangnya Kampung Wisata Organik Pesona Agro masih dalam tahap trial and error. Penyebab utamanya adalah keterbatasan ahli dan latar belakang pendidikan mayoritas pengelola bukan petani, sehingga mereka memulai dari awal.

\section{PEMBAHASAN}




\section{Enrepreneurship di Kampung Wisata Organik Pesona Agro}

Kampung Wisata Organik Pesona Agro saat ini telah memiliki beberapa green house yang dapat dimanfaatkan. Salah satu green house dikelola oleh Kelompok Tani Pesona Agro, sedangkan sisanya dikelola bersama dan sebagian yang lain dikelola oleh Karang Taruna. Berbicara tentang peran entrepreneurship, Kampung Wisata Organik Pesona Agro setelah melakukan kerjasama dengan PT. Indomarco untuk penjualan sayuran - sayuran organik, pada akhir minggu melakukan penjualan di lingkungan internal Perumahan Buring Raya.

Pada awal kegiatan dilakukan, yaitu penjualan sayuran - sayuran organik pada hari sabtu dan minggu, animo masyarakat Perumahan Buring Raya sangat antusias, namun sering berjalannya waktu minat terhadap sayuran organik kian menurun. Hal tersebut dikarenakan harga jual sayuran organik lebih mahal dibandingkan dengan sayuran nonorganik. Keadaan ini sebenarnya disebabkan oleh pengolahan bahan organik yang dimiliki Kampung Wisata Organik Pesona Agro masih terbatas pada air organik melalui HIPAM, penanaman melalui green house, serta tingkat pengetahuan Kelompok Tani Pesona Agro yang masih terbatas.

Apabila dicermati berdasarkan fakta yang ada di lapangan, entrepreneurship (kewirausahaan) merupakan kombinasi dari perilaku inovatif, proaktif serta berani menanggung risiko sehingga mampu menciptakan suatu nilai dalam organisasi (McDougall dan Oviatt, 2010). Akan tetapi, Kampung Wisata Organik Pesona Agro tampak belum melakukan tindakan - tindakan inovatif, baik dari sisi pengelolaan sayuran atau tanaman organik. Hal tersebut diikuti dengan tindakan kurang proaktif serta cenderung menghindari risiko. Apabila Kampung Wisata Organik Pesona Agro memiliki entrepreneurship maka ketika animo dan antusiasme masyarakat terhadap sayuran organik mengalami penurunan, pengelola Kampung Wisata Organik Pesona Agro yaitu Kelompok Tani Pesona Agro, Karang Taruna dan HIPAM harus melakukan tindakan - tindakan inovatif, proaktif dan mau menganggung risiko.

Memang Kampung Wisata Organik Pesona Agro sudah melakukan tindakan proaktif yaitu bekerjasama dengan PT. Indomarco, serta berani menanggung risiko terhadap proses pengelolaan tanaman organik. Namun, momen ketika kerjasama dengan PT. Indomarco mengalami gangguan, pengelolaan atau produksi sayuran organik di Kampung Wisata Organik

Pesona Agro secara langsung terdampak dan belum dilakukan tindakan - tindakan inovatif maupun proaktif untuk menanggulangi hal tersebut. Sumber terjadinya hal tersebut adalah entrepreneurship hanya dimiliki oleh beberapa orang di dalam organisasi yang ada di Perumahan Buring Raya yaitu Karang Taruna, HIPAM dan Kelompok Tani. Setiap anggota dalam organisasi - organisasi tersebut seharusnya memiliki keberanian untuk melakukan usaha secara mandiri dan berani menanggung segala risiko yang akan dihadapi serta berdedikasi untuk menjalankan bisnis hingga berhasil, dalam hal ini setiap anggota wajib berusaha hingga Kampung Wisata Organik Pesona Agro berhasil berbisnis sayuran organik (Oswari (2005).

Salah satu pengembangan entrepreneurship adalah social entrepreneurship, yaitu sebuah perilaku yang dilaksanakan dalam bentuk pelaksanaan nilai sosial melalui berbagai kesempatan oleh individu, kelompok atau organisasi terhadap lingkungan yang ada agar menjadi lebih baik (Weerawardena dan Mort, 2006; Nicholls, 2009). Hal ini sesuai dengan latar belakang antusiasme masyarakat Perumahan Buring Raya ketika mewujudkan Kampung Wisata Organik Pesona Agro adalah agar lingkungan sekitar menjadi lebih baik, asri serta hijau.

Hal - hal yang dilakukan oleh Karang Taruna, HIPAM maupun Kelompok Tani Pesona Agro adalah untuk mengelola tanaman organik merupakan bentuk nyata dari pelaksanaan social entrepreneurship, karena apabila masyarakat Perumahan Buring Raya menanam sayuran organik di setiap pekarangan rumah, mampu menciptakan dampak positif bagi lingkungan karena menjadi lebih asri.

\section{Kualitas Sumber Daya Manusia}

Penting bagi setiap organisasi bisnis manapun untuk memiliki SDM yang berkualitas, tidak terkecuali bagi Kampung Wisata Organik Pesona Agro. Setiap bisnis yang berhasil, selalu memiliki kualitas SDM terbaik. Berbeda dengan yang seharusnya, kenyataan dilapangan menunjukkan bahwa Kampung Wisata Organik Pesona Agro memiliki keterbatasan ahli dan ketersediaan 
waktu dalam pengelolaan. Hal tersebut disebabkan oleh mayoritas pengelola adalah purnawirawan (beberapa masih aktif namun mendekati masa pensiun) dan pengelolaan tanaman organik bukan pekerjaan utama, melainkan pekerjaan sampingan yang dikerjakan diluar pekerjaan utama. Rata - rata pekerjaan utama pengelola Kampung Wisata Organik Pesona Agro adalah Tentara Nasional Indonesia (TNI), Dosen, Guru, Pengacara dan Pengusaha serta Ibu Rumah Tangga, dimana pekerjaan - pekerjaan tersebut merupakan pekerjaan utama mayoritas pengelola. Untuk pekerjaan utama lainnya bukan bagian dari pekerjaan pengelola Kampung Wisata Organik Pesona Agro.

Kualitas sejatinya adalah suatu keseluruhan ciri dan karakteristik yang dimiliki suatu produk dan jasa yang dapat memberikan kepuasan pada penggunanya (Yulianto, 2010). Kampung Wisata Organik Pesona Agro dalam hal ini belum mampu memaksimalkan kepuasan pengguna tanaman organik. Untuk menanggulangi kepuasan pelanggan, upaya yang selama dilakukan adalah penanaman tanaman organik tersebut dilakukan berdasarkan pesanan apabila dalam jumlah yang banyak, sedangkan untuk produktivitas harian tanaman organik belum mampu menghasilkan tanaman organik yang bervariasi karena terkendala oleh berbagai macam hal, dimana salah satunya adalah pengelolaan tanaman organik adalah pekerjaan sampingan.

Kualitas adalah conformance sehingga dikatakan sebagai produk yang berkualitas apabila produk tersebut mampu menimbulkan kepuasan konsumennya, sehingga pemilik usaha harus berusaha untuk mengetahui apa yang diinginkan oleh konsumennya (N. Logothetis, 1991:83). Upaya yang selama ini dilakukan adalah penanaman tanaman organik berdasarkan pesanan, sehingga kepuasan pelanggan dapat tercapai. Namun, pesanan tanaman organik belum mampu menutup biaya produksi, dalam hal ini masih banyak pelanggan yang lebih suka tanaman non-organik karena harga jual lebih murah, dan mayoritas belum berfikir sampai pada kesehatan jangka panjang akan makanan yang dikonsumsi. Hal tersebut saat ini terlihat dari penjualan yang kurang masif atau seadanya. Jika Kampung Wisata Organik Pesona Agro mampu meningkatkan kualitas SDM, dimana akan berdampak pada hasil produksi yang lebih baik, maka dapat dipastikan pelanggan akan puas. Hardiningsih
(2011) menambahkan bahwa kualitas adalah suatu kondisi dinamis yang berhubungan dengan produk, jasa manusia, proses, dan lingkungan yang memenuhi atau melebihi harapan pihak yang meng- inginkannya.

Tanaman Organik adalah salah satu bentuk usaha di bidang pertanian yang saat ini sedang giat untuk dikembangkan. Salah satu bentuk usaha tani seperti Kampung Wisata Organik Pesona Agro sebenarnya memiliki definisi yaitu suatu tempat atau bagian dari permukaan bumi dimana kegiatan pertanian diselenggarakan oleh seorang petani tertentu apakah ia seorang pemilik atau orang yang digaji. Apabila dilihat dari ketersediaan generasi muda, Kampung Wisata Organik Pesona Agro melalui Karang Taruna memiliki kualitas Sumber Daya Manusia yang baik. Kondisi tersebut menyebabkan Karang Taruna memiliki posisi strategis. Apabila dicermati, tujuan pembentukan Karang Taruna adalah sebagai wadah bagi generasi - generasi muda agar memiliki tempat yang positif dalam menyalurkan bakat dan kreativitas yang dimiliki, selain untuk mengembangkan kemampuan dan keterampilan individu (Wispandono et al., 2014). Karang Taruna di Kampung Wisata Organik Pesona Agro, berperan strategis dalam pengelolaan green house yaitu anak - anak muda yang ada diberdayakan dengan cara ikut mengelola tanaman organik yang terletak di setiap green house diluar jam belajar anak - anak muda tersebut, seperti hari sabtu dan minggu, atau sore hari. Apabila hal ini dapat dilaksanakan secara konsisten, maka Kampung Wisata Organik Pesona Agro sudah berada diproses yang baik, yaitu memiliki kualitas SDM maupun hasil produksi tanaman organik.

\section{Pengembangan Kampung Wisata Organik}

Melalui momentum Festival Rancang Malang, yaitu Lomba Kampung Tematik. Kampung Wisata Organik Pesona Agro memiliki momen untuk menggiatkan kembali animo masyarakat seperti saat meraih kemenangan dalam kegiatan Kampung Bersinar pada tahun 2013. Ketika penelitian ini dilaksanakan, sebenarnya setiap pekarangan rumah harus memiliki tanaman organik, ataupun tanaman sehingga pekarangan dan lingkungan sekitar rumah menjadi asri. Selain itu, tanaman - tanaman yang ada di pekarangan rumah tersebut dapat diperjualbelikan oleh antar pemilik rumah. Kemudian, dengan memiliki 
banyak tanaman organik maka setiap warga yang ada di Kampung Wisata Organik Pesona Agro menjadi lebih sehat dari sisi konsumsi makanan. Kenyataan yang terjadi adalah, tidak semua pekarangan rumah terisi oleh tanaman organik. Penyebab utamanya adalah pekerjaan utama merupakan alasan terbatasnya waktu untuk melakukan penanaman tanaman organik di pekarangan rumah. Namun, pada tahun 2015 kerjasama dengan PT. Indomarco menjadi harapan bagi pengembangan Kampung Wisata Organik Pesona Agro, walaupun saat ini harus berhenti ditengah jalan karena terjadi kesalahpahaman.

Selain itu, Kampung Wisata Organik Pesona Agro sebenarnya telah bekerjasama dengan Perguruan Tinggi di Kota Malang untuk pengembangan potensi yang ada, namun kerjasama tersebut masih dalam tahap awal dan membutuhkan waktu untuk memperlihatkan pengaruh dari kerjasama tersebut. Upaya pengembangan usaha Kampung Wisata Organik Pesona Agro lainnya yaitu kegiatan pemberian motivasi serta ilmu pemasaran. Kegiatan tersebut bertujuan untuk meningkatkan kesadaran masyarakat bahwa tanaman organik sangat bermanfaat bagi tubuh apabila dikonsumsi dan metode pemasaran modern yang dapat dikembangkan adalah melalui media internet seperti media sosial facebook maupun instagram, kemudian metode mouth- to-mouth juga penting untuk diterapkan karena kepercayaan akan kesehatan merupakan hal mutlak atas konsumsi tanaman organik.

Melalui momentum Festival Rancang Malang pada tahun 2016, Kampung Wisata Organik Pesona Agro melalui Kelompok Tani Pesona Agro, Karang Taruna serta HIPAM telah merencanakan untuk mengembangkan pengelolaan kolam ikan untuk penanaman tanaman organik. Pengembangan tersebut untuk menanggulangi keterbatasan tempat yang dimiliki oleh Kampung Wisata Organik Pesona Agro. Saat ini salah satu green house yang dikelola Karang Taruna mampu menghasilkan sekitar 2 ton sayuran, apabila tidak terkendala masalah cuaca. Pengembangan kolam ikan tersebut nanti akan menciptakan simbiosis mutualisme antara tanaman organik dan ikan,

\section{DAFTAR RUJUKAN}

1. Crecente-Romero, Fernando, Mónica Giménez-Baldazo, dan Luis F. RiveraGalicia. 2016. "Subjective Perception of Entrepreneurship. Differences Among dimana ikan yang dimaksud adalah ikan air tawar, dan simbiosis mutualisme yang dimaksud adalah air kolam selain untuk ikan, dapat digunakan untuk mengairi tanaman organik. Terkait pengembangan usaha tersebut, sayangnya Kampung Wisata Organik Pesona Agro masih dalam tahap trial and error. Penyebab utamanya adalah keterbatasan ahli dan latar belakang pendidikan mayoritas pengelola bukan petani, sehingga mereka memulai dari awal.

\section{KESIMPULAN DAN SARAN}

Berdasarkan pada tujuan dari penelitian ini yaitu bagaimana peran entrepreneurship serta kualitas Sumber Daya Manusia bagi pengembangan usaha di Kampung Wisata Organik Pesona Agro yang ada di Kelurahan Wonokoyo Kecamatan Kedungkandang Kota Malang, maka kesimpulan penelitian ini adalah bagi pengelola Kampung Wisata Organik Pesona Agro yang teridir dari Kelompok Tani Pesona Agro, Karang Taruna dan HIPAM, sejatinya belum memiliki entrepreneurship. Hal tersebut terlihat dengan penjualan hasil tanaman organik yang belum masif. Kemudian, terkait dengan kualitas SDM, Kampung Wisata Organik Pesona Agro memiliki keterbatasan jumlah ahli dan waktu untuk mengelola tanaman organik karena selama ini pengelolaan tersebut adalah pekerjaan sampingan diluar pekerjaan utama. Selanjutnya, melalui Karang Taruna generasi - generasi muda sebenarnya mampu diberdayakan, hanya saja mayoritas masih berstatus pelajar sehingga waktu yang tersedia untuk ikut mengelola yaitu penanaman organik hanya pada hari sabtu dan minggu atau pada waktu sore hari. Saran bagi penelitian selanjutnya adalah bagaimana entrepreneurship di- pengaruhi oleh tingkat pendidikan. Hal ini karena pendidikan merupakan salah satu kunci untuk mencapai kesuksesan, dalam hal ini Kampung Wisata Organik Pesona Agro apabila telah memiliki potensi - potensi generasi muda serta berpendidikan, seharusnya kesuksesan tersebut lebih mudah didapat apabila dibandingkan dengan Kampung yang tidak memiliki entrepreneurship serta kualitas SDM yang direpresentatifkan oleh generasi muda.

Countries." Journal of Business Research 69(11): 5158-62.

2. Ciptani, Monika Kussetya. 2004. Pengukuran Biaya Kualitas: Suatu 
Paradigma Alternatif. Jurnal Akuntansi dan Keuangan 1(1): 68-83.

3. Handayani, Annisa Yulia, Ninuk Purnaningsih, dan Ma Sarma. 2015. "Persepsi Pemuda Terhadap Peranan Karang Taruna Dalam Penanganan Masalah Sosial." Jurnal Penyuluhan 11(1): 1-10.

4. Hardiningsih, Pancawati. 2011. "Faktor Faktor Yang Mempengaruhi Kemauan Membayar Pajak." Jurnal Dinamika Keuangan dan Perbankan 3(1): 126-43.

5. Harsojo, dan June Mellawati. 2009. "Determination of Mineral Contain and Bacteria Contaminant on Organic and Nonorganic Fresh Vegetables." Indonesian Journal of Chemistry 9(2): 226-30.

6. McDougall, Patricia Phillips dan Benjamin M. Oviatt. 2010. "International Entrepreneurship: The Intersection of Two Research Paths." The Academy of Management Journal 43(5): 902-6.

7. Nicholls, Alex. 2009. "We Do Good Thins, Don't We?': 'Blended Value Accounting' in Social Entrepreneurship." Accounting, Organizations and Society 34(6-7): 755-69.

8. Oswari, Teddy. 2005. "Membangun Jiwa Kewirausahaan (entrepreneurship) 'Menjadi Mahasiswa Pengusaha (Entrepreneur Student) Sebagai Modal Untuk Menjadi Pelaku Usaha Baru."' In Seminar Nasional PESAT, Jakarta, 23-24.

9. Sinaga, Jayagust Hariansyah K.A. Junior, Supriadi, dan Alida Lubis. 2014. "Analis is
Pengaruh Tekstur Dan C-Organik Tanah Terhadap Produksi Tanaman Ubi Kayu (Manihot Esculenta Crantz) Di Kecamatan Pegajahan Kabupaten Serdang Bedagai." Jurnal Online Agroteknologi 2(2337): 1439-50.

10. Siswoyo, H. Bambang Banu. 2009. "Pengembangan Jiwa Kewirausahaan Di Kalangan Dosen Dan Mahasiswa." Jurnal Ekonomi dan Bisnis 14(2): 35-45.

11. Weerawardena, Jay dan Gillian Sullivan Mort. 2006. "Investigating Social Entrepreneurship: A Multidimensional Model." Journal of World Business 41(1): 21-35.

12. Widodo, Diah Rina Kamardiani, dan Lestari Rahayu. 2016. "Minat Konsumen Terhadap Beras Organik Di Daerah Istimewa Yogyakarta Dan Jawa Tengah.” Jurnal Agraris 2(2): 134-42.

13. Wispandono, R. M. Mochammad, Deni Setya Bagus Yuherawan, dan Farida Nurul Rahmawati. 2014. "Penanggulangan Pengangguran Melalui Pemberdayaan Karang Taruna Di Kabupaten Sampang (Kajian Dari Analisis Sumber Daya Manusia)." Jurnal PAMATOR 8(1): 3546.

14. Yulianto, Arief. 2010. "Meningkatkah Kualitas Pelayanan Jasa Penerbangan Indonesia Paska Insiden Kecelakaan Pesawat Terbang?" Jurnal Dinamika Manajemen 1(1): 1-8. 